\title{
UTILIZATION AND SUITABILITY OF THE INFORMATION TECHNOLOGY TASK AGAINST THE PERFOMANCE OF SEMARANG TAX OFFICE
}

\author{
Vincent Bastian Tertio Sayudha \\ Universitas Negeri Semarang \\ vincentbts18@gmail.com
}

\begin{abstract}
Information technology has become part of human life to work, even it is very important in business organizations to be important in the timeliness and correctness of the provision of information technology at work. The purpose of this study is to analyze and describe influence information technology and technological tasks individual performance. The population in this study were employees of the Candisari Pratama Tax Service Office, the South Semarang Pratama Tax Service Office, the East Semarang Pratama Tax Service Office. The sampling used in this study used a purposive sampling method and obtained 100 tax employee respondents. The analysis technique used in this study is multiple regression analysis with the application of IBM SPSS 23. The results of this study indicate the use of information technology and the suitability of the information technology task are significantly related to individual performance. The advice given related to this research is that the pratama tax office needs to help improve information technology by adding supporting facilities provided by users and increasing the level of conformity of information technology tasks in compiling tax revenue based on resources that can help individuals with the maximum number of employees.
\end{abstract}

Keywords: utilization, tasks suitability, and individual performance.

\section{INTRODUCTION}

Information technology in business organizations becomes important in the timeliness and correctness of providing information needed by users. The development of information technology needs to be supported by many factors that are expected to provide success from the information system itself which is reflected through the satisfaction of users of information technology. Information technology has become the first choice in creating an organization's information system that is resilient and capable of giving birth to competitive advantage in the midst of increasingly fierce competition in this globalization era. 
Himawan and Rizki (2016) the use of information technology has a person's knowledge in the environment that can be influenced by individual feelings towards computer use, social factors in the workplace environment that use computers, social factors in the workplace environment that uses computers, individual habits when using computers, the consequences felt by individuals expected from the use of computers, and the conditions that facilitate in a conducive environment using computers and other technological tools.

The Kupang Primary Tax Service Office occurred in 2019 implementing and launching information technology applications. The head of the Kupang KPP Primary stated that to utilize information technology to improve efficiency and effectiveness is very helpful in carrying out the work unit by implementing and launching the FAQs application via QR Code about tax services. Implementing and utilizing the application FAQs via QR Code presents several stakeholder-oriented taxation information services through information technology applications, information technology applications must continue to require the full commitment of each worker in improving the quality of services to compulsory tax. This innovation is an embryo of information technology-based innovation which will later be developed by KPP Pratama Kupang. KPP Pratama Kupang hopes that tax employees and taxpayers commit to innovation that can be one of the contributions to realize voluntarily tax compliance and also in achieving the utilization of information technology is needed to see the implementation of the program being run.

\section{LITERATURE REVIEW}

\subsection{Information Technology}

The results of research from Giovanie and Rizki (2016) state that partially the influence of the use of information technology has a significant effect on the individual performance of tax employees . Meanwhile, Inuk Wahyuni (2016) shows that the use of information technology on individual performance has a significant effect, the results of this test indicate that the use of information technology in terms of intensity or frequency of use and type of software controlled by users has a positive influence in improving or increasing individual performance. and bring significant changes to individual performance.

The results of research from Agnes and Albertus (2013) state that the "suitability of technological tasks has a positive influence on individual performance". Meanwhile, the research of Agnes and Albertus (2013) "which stated that the suitability of technological tasks had a significant influence on individual performance".

The purpose of this study is to examine the effect of the use of information technology and the suitability of information technology tasks on the performance of individual tax employees. The authenticity of this test is that the researcher tries to test the utilization of information technology and the suitability of the information technology task. Previous studies generally discuss the characteristics of the task, the characteristics of technology, usage, the suitability of the technology for the task. In addition, the object of research in this study are employees of the Primary Tax Service Office in the City of Semarang.

There are several definitions of information technology from various experts in the field of computer science 
as according to the Information Technology Association of America (2000) defines information technology as the process of storing and disseminating pictorial, vocal, and text information to reduce the misalignment of information that exists between managers and shareholders with use outsiders to provide endorsement of financial statements. In addition, Haag and Keen (1996) define information technology as a set of tools that help work with information and perform tasks related to information processing. Information technology is seen as the ability of facilities in the field of technology to improve quality and facilitate work every day.

\subsection{Utilization of Information Technology}

According to Thomas et al (1991) the use of information technology is the expected benefits by users of information systems in carrying out their duties or behavior in using technology when doing work (Putu Diah and I Made, 2016). Utilization of information technology that is supported by the activities of personnel will support in saving time and costs as well as increasing effectiveness in achieving a report of the company or business organization correctly.

\subsection{Suitability of Information Technology Tasks}

According Jogiyanto (2008) states that the suitability of information technology tasks is an idea profile formed from a collection of task dependencies that are internally consistent with the elements of technology used that will result in performance (Agnes and Albertus, 2013). The suitability of information technology tasks triggers the use of information technology to work in order to adjust existing information technology tasks according to company procedures.

\subsection{Individual Performance}

According to Mangkunegara (2005) individual performance is the quality of work and achieved by employees in carrying out their duties in accordance with the responsibilities given to employees (Himawan and Rizki, 2016). Performance has limits as a person's success in carrying out tasks as work that is charged by each person to judge for himself or the organization concerned.

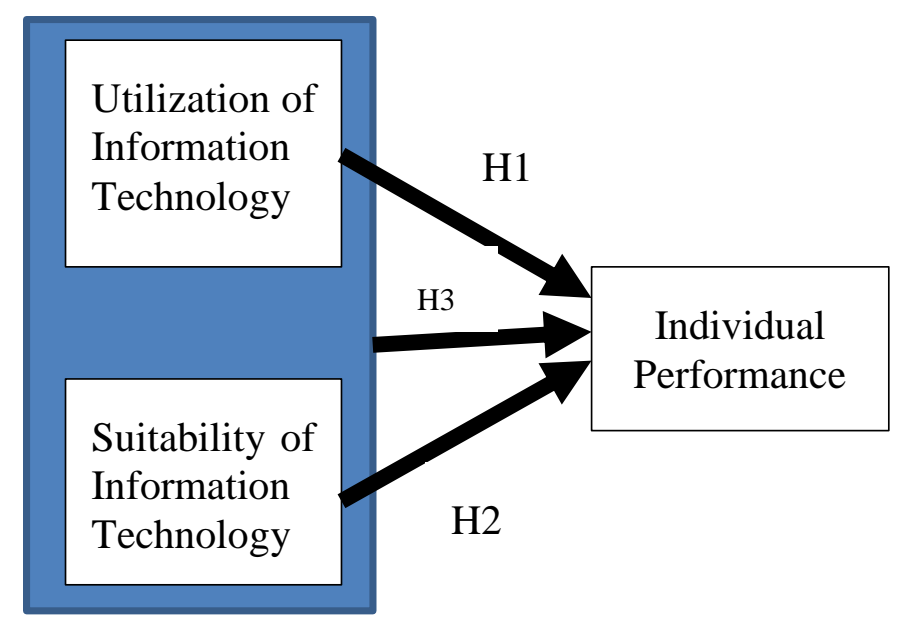

\section{RESEARCH METHOD}

\subsection{Data Collection Techniques}

The data used are primary data that is done with the results of calculating and measuring data and obtained from the answers of employees of the Pratama Tax Office.

\subsection{Operational Definitions of Variables}

This study uses three variables, namely the utilization of information technology and the suitability of information technology tasks as an independent variable, individual performance as the dependent variable. 


\subsection{Sample Collection Techniques}

The population in this study are tax employees at Candisari Pratama Tax Service Office, Pratama Tax Service Office, South Semarang, Pratama Tax Service Office, East Semarang. Samples were selected using purposive sampling so that a total of 100 respondents can be obtained, the sampling criteria in this study were taken from the general field and internal compliance, the field of data and information processing, and the service sector. Each pratama tax office has a number of different employees according to the three fields, namely the Candisari Primary Tax Service Office has 31 employees, the South Semarang Pratama Tax Service Office has 24 employees, the East Semarang Pratama Tax Service Office has 44 employees. Sample selection criteria can be seen in table 1.

Table 1. Sample Selection Process

\begin{tabular}{|l|l|l|}
\hline No & Criteria & Total \\
\hline 1 & KPP Candisari & $\mathbf{3 1}$ \\
\hline
\end{tabular}

\begin{tabular}{|l|l|l|}
\hline 2 & $\begin{array}{l}\text { KPP Semarang } \\
\text { Selatan }\end{array}$ & $\mathbf{2 4}$ \\
\hline 3 & $\begin{array}{l}\text { KPP Semarang } \\
\text { Timur }\end{array}$ & $\mathbf{4 4}$ \\
\hline 4 & $\begin{array}{l}\text { Total tax } \\
\text { employee } \\
\text { analysis }\end{array}$ & $\mathbf{1 0 0}$ \\
\hline
\end{tabular}

Source: Secondary Data, 2020

\subsection{Data Analysis Techniques}

Descriptive statistical analysis functions to describe or describe the object under study through sample data or population, without conducting analysis and making conclusions that are applicable to the public. Descriptive statistics used in this study are the minimum value, the maximum value, the average value, and the standard deviation value.

\section{RESULTS AND DISCUSSION}

\subsection{Results}

Table 2. Descriptive Statistics

\begin{tabular}{|c|c|c|c|c|c|c|}
\hline & & $\mathrm{N}$ & Minimum & Maximum & Mean & $\begin{array}{c}\text { Std. } \\
\text { Deviation }\end{array}$ \\
\hline Utilization & & 100 & 42 & 68 & 58.32 & 5.941 \\
\hline Suitability & & 100 & 51 & 85 & 70.54 & 7.598 \\
\hline $\begin{array}{l}\text { Individual } \\
\text { Performance }\end{array}$ & & 100 & 30 & 50 & 42.43 & 4.877 \\
\hline $\begin{array}{c}\text { Valid } \\
\text { (listwise) }\end{array}$ & $\mathrm{N}$ & 100 & & & & \\
\hline
\end{tabular}

Source: Secondary Data, 2020

The results of descriptive statistical analysis in table 2 for information technology utilization variables show a range of values of 42 to 68 . The value of the standard deviation possessed by the information technology utilization variable is 5.941 with an average value of
58.32 so that it can be said the value of the standard deviation of the utilization variable information technology is smaller than the average value which shows that the deviation of data on the information technology utilization variable is included in the normal 
category in carrying out the use of information technology. The suitability of information technology tasks has a range of minimum and maximum values of 51 to 85 which is shown in the descriptive statistical results in table 3 . The average value of the information technology task suitability variable is 70.54 with a standard deviation of 7.598 . Variable suitability of information technology tasks also indicates a smaller standard deviation compared to the average value, it can be said that the suitability of information technology tasks have data deviations that fall into the normal category of conformity with information technology tasks. The statistical results of the individual performance variables in table 3 show the range of values from 30 to 50 . The standard deviation value owned by the individual performance variable is 4,877 with an average value of 42.43 , so it can be said that the individual performance variable also shows a smaller standard deviation compared to the average value, it can be said that individual performance variables have normal data deviations in carrying out individual performance of each employee

\subsubsection{Test of Classical Assumptions Table 3. Normality Test Result}

One-Sample Kolmogorov-Smirnov Test

\begin{tabular}{|l|l|r|}
\hline \multicolumn{2}{|c|}{} & \multicolumn{1}{|c|}{$\begin{array}{c}\text { Unstandardized } \\
\text { Residual }\end{array}$} \\
\hline \multirow{2}{|c|}{$\mathrm{N}$} & 100 \\
\hline \multirow{2}{*}{$\begin{array}{l}\text { Normal } \\
\text { Parameters }\end{array}$} & Mean & .0000000 \\
\cline { 2 - 3 } & $\begin{array}{l}\text { Std. } \\
\text { Deviation }\end{array}$ & 2.28529616 \\
\hline $\begin{array}{l}\text { Most } \\
\text { Extreme } \\
\text { Differences }\end{array}$ & Absolute & Positive \\
\cline { 2 - 3 } & Negative & .084 \\
\hline \multirow{2}{*}{ Test Statistic } & & .084 \\
\hline Asymp. Sig. (2-tailed) & -.078 \\
\hline
\end{tabular}

Source: Secondary Data, 2020

The normality test results show that the Kolmogorov-Smirnov (KS) value is 0.077 and this value is greater than the 0.05 level significance so that it can be concluded that the data are normally distributed.

Table 4. Multikolinearitas Test Result

\begin{tabular}{|rcc|}
\hline Model & \multicolumn{2}{c|}{ Collinearity Statstics } \\
& Tolerance & VIF \\
Utilization & 0,478 & 2,094 \\
Suitability & 0,478 & 2,094 \\
\hline
\end{tabular}

Source: Secondary Data, 2020

Multicollinearity test is known that the VIF value $<10$ and tolerance value $>0.10$ so that it can be concluded that the data is free from multicollinearity.

Table 5. Heteroskesdatisitas Test Result

\begin{tabular}{|lcc|}
\hline Model & $\mathrm{T}$ & Signifikansi \\
Utilization & 0,552 & 0,582 \\
Suitability & $-1,151$ & 0,252 \\
\hline
\end{tabular}

Source: Secondary Data, 2020

Heteroskesdatisitas test carried out using glacier tests showed that from each variable the significance value is more than 0.5 , this shows that the data is free from the existence of heteroskesdatisitas.

\subsubsection{Hypotesis Test}

\begin{tabular}{|lc|}
\multicolumn{1}{c}{ Table 6. } & F Test Result \\
\hline Model & Sig. \\
Regression & $.000^{\mathrm{b}}$ \\
\hline Source: Secondary Data, 2020
\end{tabular}

The results of the $f$ test on the variable information technology utilization and suitability of information technology tasks have an $F$ count 172.336> F table 3.09 and a significance value of 0.000 at 
a significance level of 0.05 , so it can be concluded that $0.000<0.05$, the technology utilization hypothesis information and the suitability of information technology tasks (H3) which are counted together (simultaneously) and reads "Utilization of Information Technology and the suitability of information technology tasks simultaneously have a positive effect on individual performance", accepted

\subsection{Discussion}

$\mathbf{H}_{1}$ : Significance test results of the statistical test of $t$ indicate that partially the utilization of information technology variables has a significant influence on individual performance so that the first hypothesis in this study is accepted, this states that the better the utilization of information technology, the better the performance of tax employees for the tax office, conversely, if the performance is not better in the use of information technology, then the performance of tax employees will also decrease for the tax office.

$\mathbf{H}_{2}$ : The results of the test of the significance of individual parameters $(t$ test statistic) show that partially the suitability of information technology tasks has a significant effect on the performance of individual tax service

\section{REFERENCES}

A.A, Anwar Prabu Mangkunegara. (2010). Evaluasi Kinerja Sumber Daya Manusia. Bandung: PT. Refika Aditama.

A. Dale Timpe. (1992). Kinerja. Jakarta: PT.Gramedia.

Abdul, H.. (1995). Sistem Informasi Akuntansi. Yogyakarta: BPE.

Anisa, R. D. (2014). Pengaruh Sikap, Norma, Sibjektif, Kontrol Perilaku, Minat Membeli offices, so that the second hypothesis in this study is accepted, it means that the better the suitability of information technology tasks, the more the performance of tax officers for tax service offices also increases, on the contrary if the performance of information technology tasks is not better, the performance of tax officers for tax offices also decreases.

\section{CONCLUSION}

The conclusion from the results of the study shows that the use of information technology has a significant effect on individual performance, while the suitability of the information technology task has a significant effect on individual performance. Variable utilization of information technology and suitability of information technology tasks together (simultaneously) have a positive effect on individual performance. Suggestions relating to this research are the pratama tax office need to increase the use of information technology by adding supporting facilities provided by users and an increase in the suitability of information technology tasks in preparing tax revenue based on tax potential so as to increase the performance of individual employees to the maximum.

Sebagai Mediasi Terhadap Perilaku Membeli Produk Yakult. Universitas Lampung. Aprilianto, B., \& Hidayat, A. (2020). Pengaruh Bisnis E-Commerce dan Pemeriksaan Pajak terhadap Penerimaan Pajak (Studi Kasus Wajib Pajak Yang Terdaftar di KPP Kelapa Gading). EkoPreneur, 1(2), 156168.

Ashianti, A. \& Albertus F.. (2013). Pengaruh Kesesuaian TugasTeknologi, Kepercayaan, dan 
Efektivitas Sitem Informasi Akuntansi Terhadap Kinerja Individu Pada Pasar Swalayan di Kota Tangerang. Ultima Accounting. Vol.5 No.2, 2013.

Geovannie, H. L., Kertahdai \& Rizki Y. D.. (2016) Pengaruh Pemanfaatan Teknologi Informasi dan Kesesuaian Tugas _ Teknologi Informasi Terhadap Kinerja Individual Pemerintahan (Studi Kasus Pada Kantor Pelayanan Pajak Pratama Malang Selatan). Junral Perpajakan. Vol. 8 N0. 1, 2016.

Goodhue L \& Thompson. (1995). TaskTechnology Fit and Individual Performance. U.S.A.

Gusnetti. (2014). Faktor-faktor Yang Mempengaruhi Kinerja Karyawan Pada PT. Garuda Indonesia Pekanbaru. Jom FISIP. Vol. 1, No. 2.

Hariyanto, W. (2012). Pengaruh Kesesuaian Tugas Teknologi dan Pemanfaatan Teknologi Informasi Terhadap Kinerja Akuntan Publik di Surabaya. Emisi Vol.1 No.2 Oktober 2018 181-188.

Lindawati, HJ, Irmasalamah. (2012). Pemanfaatan Sistem Informasi dan Teknologi Informasi Terhadap Kinerja Individual Karyawan. Jurnal Akuntansi dan Keuangan. Vol. 14, No. 1 Mei 2012 56-68.

Ma'arif, S. M., Anggraeni, S. \& Dessy D. (2013). Faktor-faktor yang Mempengaruhi Kinerja Pegawai: Studi di Perusahaan Daerah Pasar Tohaga Kabupaten Bogor. Jurnal Aplikasi Manajemen. Vol. 2, No. 2.

Melati, I. I. (2011). Faktor-faktor Yang Mempengaruh Kinerja Pegawai. Fakultas Ekonomi Universitas Diponegoro.

Mirnasari, P. D. \& I Made Sadha Suardhika. (2018). Pengaruh
Penggunaan Teknologi Informasi, Efektivitas Sistem Informasi Akuntansi, dan Sistem Pengendalian Intern Terhadap Kinerja Karyawan. E-Jurnal Akuntansi Universitas Undayana. Vol.23 No.1, 2018.

Murgianto ; Siti Sulasmi ; Suhermin. (2016). The Effects of Commitment, Competence, Work Satisfaction Motivation, and Perfomance of Employess at Integrated Service Office of East Java. International Journal of Advanced Research (2016). Volume 3, Issue -378-396.

Nazwirman. (2019). Analysis of Employee Performance: A Case Study In Port Corporation. Jurnal Organisasi dan Manajemen 15 (1)2019, 24-3.

Novitasari, Dhea. (2015). Pengaruh Minat Pemanfaatan Sistem Informasi Terhadap Penggunaan Sistem Informasi dan Dampaknya Pada Kinerja Individu. Universitas Pasundan.

Nuskiya, Aliyar Fathima. (2018). The Effect of Information Technology on Employees' Performance in the Banking Industry in Sri Lanka. Empirical Study Based on the Banks in Ampara District. European Journal of Business and Management.

ISSN 2222-1905 (Paper) ISSN 2222-2839 (Online). Vol.10, No.16, 2018.

Rachmawati, Yeni. (2019). "KPP Pratama Kupang Luncurkan FAQs via QR Code Seputar Layanan Perpajakan". https://kupang.tribunnews.com/. Diakses tanggal 02 Juni 2020.

Rifzan. (2019). Penjelasan Mengenai Perkembangan TI Indonesia. Jakarta: Robicomp. (Kamis, 14 Maret 2019). 
EAJ (Economics and Accounting Journal) - Vol. 3, No. 3, Sept 2020 - Sayudha

Salim, Kalbin ; Mira Puspa Sari. (2015). Pengaruh Globalisasi Terhadap Dunia Pendidikan. STAI Abdurahman Kepulauan Riau.

Saputri, N. (2013). Faktor-faktor Yang Mempengaruhi Kinerja. Makalah. Samarinda.

Sayekti, F. \& Pulasna P.. (2016). Penerapan Technology

Susilawati, Clara ; Sri Sunarti. (2011). Faktor-faktor Yang Mempengaruhi Pemanfaatan Teknologi Informasi Oleh Akuntan. Jurnal Dinamika Akuntansi. Vol. 3, No. 2.

Thompson et.al. (1991). Personal Computing: Toward A Conceptual Model of Utilization. MIS Quarterly 125-143.

Wahyuni, I. (2016). Faktor - faktor Yang Mempengaruhi Pemanfaatan Teknologi Informasi Dan Pengaruh Pemanfaatan Teknologi Informasi Terhadap Kinerja Individual. Jurnal Akuntansi Riset UPI. ISSN 2086 $-2563$
Acceptance Model (TAM)

Dalam Pengujian Model

Penerimaan Sistem Informasi

Keuangan Daerah. Universitas Teknologi Yogyakarta.

Subhan, M. (2019). Teknologi Informasi di Indonesia. Kompasiana. (Selasa, 08 Oktober 2019).

Widagdo, P. P., Tony Dwi Susanto \& Ramadiani. (2016). The Effect of Task Technology Fit Toward Individual Performance on theGeneration X (1956-1980) using Information Technology. 2nd International Conference on Science in Information Technology (ICSITech).

Widagdo, P. P. \& Tony, D. S. (2016). Pengaruh Kesesuaian Teknologi Pada Tugas ( Task Technology FIT ) Terhadap Kinerja Individu Dalam Menggunakan Teknologi Informasi. Prosiding Seminar Nasional Manajemen Teknologi XXIII 